\title{
MEDICAL RESEARCH IN THE SUDAN SINCE 1903*
}

\author{
by
}

\section{A. BAYOUMI**}

EARLIER HISTORY OF MEDICAL RESEARCH IN THE SUDAN 1903-1948

ORGANIZED MEDICAL RESEARCH in the Sudan, which was a development of the early years of this century at a time when proper medical administration in the country was hardly in existence, owed its inception to the initiative of a great humanitarianMr. (later Sir) Henry S. Wellcome-the founder of what is known today as the Wellcome Foundation. It was against the background of the explosion of knowledge in the field of medicine in the closing decades of the nineteenth century, when the work of medical scientists such as Robert Koch and Louis Pasteur was establishing a genuinely scientific aetiological basis for disease, that Wellcome donated in 1902 the equipment of a research laboratory together with a library and museum as a generous gift to the Sudan Government.

In February 1903, Dr. (later Sir) Andrew Balfour commenced work at the Wellcome Tropical Research Laboratories in Khartoum. Balfour was a medical pioneer in many directions and besides being the first incumbent of the post of Director to the laboratories, he also held the posts of first Medical Officer of Health to Khartoum Province and Sanitary Adviser to the Sudan Medical Department. These two additional responsibilities, as we shall see later, were bound to influence the initial direction of medical research in the Sudan.

The Wellcome Laboratories, which were housed in four rooms on the second floor of the east wing of Gordon Memorial College (now the University of Khartoum), were intended to serve the following objectives: ${ }^{1}$ (1) to promote technical education; (2) to promote the study of tropical disorders, especially the infective diseases of both man and beast peculiar to the Sudan, and to render assistance to the officers of health, and to the clinics of the civil and military hospitals; (3) to aid experimental investigations in poisoning cases by the detection and experimental determination of toxic agents, particularly the obscure potent substances employed by natives; (4) to carry out such chemical and bacteriological tests in connexion with water, foodstuffs, and health and sanitary matters as may be found desirable; (5) to undertake the testing and assaying of agricultural, mineral and other substances of practical interest in the industrial development of the Sudan. While these broad statements strongly suggested that general scientific research, at that time, could no more be divorced entirely from purely medical work than could routine laboratory investiga-

*This paper is part of a Khartoum University M.D. thesis.

**A. Bayoumi, M.D., D.P.H., is Senior Lecturer in the Department of Community Health, University of Nairobi. He was formerly Lecturer in the Department of Preventive Medicine, Makerere University, Kampala. 


\section{A. Bayoumi}

tions from research, their multidisciplinary approach was perhaps the most appropriate way of tackling the research aspects of a vast and problematic country like the Sudan.

Although the laboratories were annexed to the Gordon Memorial College, they remained independent from both the Medical Department and the Department of Education, and Balfour was in sole charge though nominally owing allegiance to the Director of Education, Sir James Currie. The initial staff consisted only of the Director, a laboratory assistant and two Sudanese laboratory attendants; but in 1904 a well-trained chemist-Dr. W. Beam-was appointed as first chemist, and in $1906 \mathrm{Mr}$. H. H. King joined the staff as first entomologist. In those early years the laboratories also benefited from the services of a "collector" who was described by Balfour as: ". . . a trained observer whose duty was to traverse the country and collect blood films, biting and injurious insects, parasites, photographs of pathological conditions among natives, drugs, poisons, and indeed anything having a bearing on tropical medicine in the Sudan. Such work, properly conducted, might be invaluable and lead to many interesting discoveries."2

Besides establishing the germ of medical research and being a great asset to medical work in the Sudan, the Wellcome Laboratories established good links with the London and Liverpool Schools of Tropical Medicine; and Balfour ${ }^{3}$ stated in this connexion that his laboratories acted as a liaison for providing these centres with teaching material and aided the Cancer Research Fund in its inquiries. By the time they completed their first anniversary, the laboratories were equipped with a good museum and a well-stocked library. The museum was primarily devoted to the collection and exhibition of specimens and photographs showing the diseases of man and animals in the Sudan, together with maps showing their respective distribution. The library was supplied with a selection of the necessary scientific journals and periodicals: and the United States Department of Agriculture and the British Museum provided it with some of their valuable publications.

In the ten years that Dr. Balfour was the Director, he conducted routine investigations and carried out research into most of the common diseases; but his activities were centred upon the sanitation of Khartoum. He achieved notable success by his investigations into mosquitoes and other biting and noxious insects. His keen interest in environmental sanitation had alerted him to the malarial problem immediately he arrived in the Sudan. In those days, although mosquito-nets and prophylactic quinine were commonly used, the fight against mosquito larvae as a means of reducing mosquito population and hence malaria incidence was gaining ground after Major (later Sir) Ronald Ross had demonstrated this at Ismailia in 1902-1905. Following Ross's experiment, Khartoum under the guidance of Balfour was well to the fore. After studying the bionomics of mosquitoes and mapping out their distribution in Khartoum, Balfour formulated a concerted plan for the containment of the disease. While individual efforts and indeed a curiosity to investigate scientific phenomena had been a feature of the work of the Wellcome Laboratories from their inception, it can generally be maintained that the medical conditions of the country and the very urgent need for preventive medicine created the demand for research. When Balfour resigned in 1913, medical research in the Sudan was already placed on a firm footing. During Balfour's directorship elaborate reports were compiled about the 
activities of the Wellcome Research Laboratories covering the period 1904 to $1911.4,5,6,7,8,9,10$

Balfour was succeeded by Dr. A. J. Chalmers as Director of the Wellcome Laboratories; but his post as the Medical Officer of Health of Khartoum was taken by Dr. L. Bousfield. Few medical personalities played as important a role in that era of pioneering medical research as did Chalmers, whose contributions to medical science were acknowledged by perpetuating his name in the Chalmers Medal of the Royal Society of Tropical Medicine and Hygiene. It was during Chalmers' directorship (1913-1920) that the systematic study of tropical diseases was undertaken. While researches were conducted into most of the tropical maladies of the Sudan, perhaps the most important contribution was in some aspects of schistosomiasis. Leiper's discovery of the snail intermediate hosts in Egypt in 1915 was confirmed by Chalmers in Khartoum; and in 1919 Christopherson successfully treated seventy cases of the disease in Khartoum Civil Hospital using intravenous tartar emetic or potassium antimony tartrate. ${ }^{11}$ As justly maintained by Squires, ${ }^{12}$ "this was probably the most significant contribution to medicine made by a member of the Sudan Medical Service."

While it is no doubt true that the seed of medical research in the Sudan which was planted by Balfour started to bud and blossom under Chalmers' leadership, the basic requirements of medical and scientific research-higher education and economic development-were in the meantime also being secured. The Gordon Memorial College was founded in 1903, instructional workshops in 1905, the training of medical auxiliaries in 1918, the Kitchener School of Medicine in 1924, and the Gezira irrigation scheme (which had notable medical implications) in 1925.

From the evidence adduced above, it would be no exaggeration to say that the Sudan was a pioneering condominium with regard to the establishment of medical research. An interesting observation which deserves mention in this connexion is that when the committee formed by Sir Alfred Milner (British Colonial Secretary) in 1919 to investigate medical administration in the colonies recommended that a medical research institute under a director should be established in every important colony or group of colonies, the research organization of the Sudan was more than seventeen years old. In its statement on research the committee said: “ . . Every witness who has been questioned on the subject has agreed that great opportunities for research in medicine and the allied sciences exist in all the tropical Colonies and owing to the absence of a Research Service they are being lost. There is no better investment for the money of any colony than scientific research, both medical and economic, and the Committee recommends the creation of such a Department as part of the Colonial Medical Service."13

While this report directed attention to the problems of research in Africa and initiated embryonic research in some colonies, ${ }^{14}$ its impact in the Sudan-though a bit belated-was also to be felt. Consequently, medical research was recognized as an official function of the medical administration of the country; in 1935, as we shall see later, the Stack Medical Research Laboratories became the research organ of the Sudan Medical Service.

In 1920 Chalmers was succeeded by Dr. (later Sir) R. G. Archibald who had 


\section{A. Bayoumi}

been serving with the laboratories since 1908. Archibald was another pioneer of medical research in the Sudan and during his fifteen years as Director, the laboratories continued research into most of the disease problems of the Sudan but became more involved in routine investigations. An exhaustive list of medical research activities up to 1937 will be found in Hill's Bibliographical dictionary of the Anglo-Egyptian Sudan. ${ }^{15}$

In 1925 the laboratories were taken over by the government under the Department of Education and in 1927 they were transferred to a new building adjacent to Khartoum Civil Hospital and Kitchener School of Medicine, built in memory of Sir Lee Stack, Governor-General of the Sudan who was assassinated in Cairo in 1924. This was-on the face of it - the sign heralding integration of medical research activities in the Sudan. It was followed ten years later by the organization of coordinated medical research under the Sudan Medical Service. During this period of transition-1925 to 1935-the Stack Laboratories formed the bacteriological unit of the Wellcome Laboratories which maintained their autonomous character until the retirement of Archibald in 1935.

The reorganization of the services dealing with scientific research in the Sudan in April 1935 made the Stack Medical Research Laboratories the official research organ of the Sudan Medical Service, and Dr. E. S. Horgan-Archibald's successor-was appointed Director to the laboratories and Assistant Director (Research) Sudan Medical Service. The Wellcome Tropical Research Laboratories ceased to exist as such, but thereafter continued to operate as the Wellcome Chemical Laboratories; and after being placed under the control of the Agricultural Research Service for the following four years, they were transferred back to the Sudan Medical Service in 1939. Another welcome move in this reorganizational effort was the creation of a special sub-section of Medical Entomology run on behalf of the Sudan Medical Service by staff seconded from the Entomological Section of the Agricultural Research Service. Mr. F. G. S. Whitfield, who had since 1930 held the post of lecturer in biology at the Kitchener School of Medicine and the Gordon Memorial College, was appointed Medical Entomologist and placed in charge of this sub-section.

Thus it was not accidental that co-ordination of medical research in the Sudan progressed at a time when scientific research in the country was reorganized. By the early 1930s the research complex of the Sudan Medical Service was composed of a tripartite structure: the Stack Medical Research Laboratories, the Wellcome Chemical Laboratories and the Entomological Laboratories. Although these laboratories formed the three limbs of the medical research triangle of the country, they were administered separately; but the Stack Medical Research Laboratories were hence destined to become a great tower of strength for the initiation and organization of medical research around the public health problems of the Sudan.

As noted already, from 1927 to 1935 the Stack Laboratories formed the bacteriological unit of the Wellcome Research Laboratories. When in 1935 they became the orbit of medical research in the Sudan, they were no longer to be administered as a detached organization; but became an integral part of the Sudan Medical Service. It was probably not accidental that this re-shaping of medical administration marked the beginning of a new epoch in the history of medical research in the Sudan when it 
triggered off, as we shall see later, a series of centrally directed research programmes. In his critical reappraisal of the conditions of medical research in the Sudan, Horgan observed that: "There is sometimes a certain tendency to lay undue emphasis on an increase of routine examinations in evaluating the efficiency of a Tropical Research Laboratory. Such increases are no doubt very gratifying but there seems a certain risk in allowing them to choke the essential research activities of such a Laboratory. In a country like the Sudan the fundamental importance of short range research demands a close liaison between it and routine examinations, the latter forming its raw material but at the same time it is equally important to hold a balance between them."16

While Horgan maintained that the increase of routine work in the previous five years had been an inevitable feature of the expansion of the health services, these statements were a clear indication of a change of medical research policy in the Sudan. To effect his new policy Horgan boosted the training of laboratory assistants to man the peripheral hospitals network thus securing better opportunities for his laboratories to deal with more sophisticated investigations and to carry out systematic research into the public health problems of the country.

Horgan's policy initiated several research projects on a practical and limited scale. The first project was malaria in the Gezira in relation to which an entomological survey was commenced under Mr. D.J. Lewis, a second medical entomologist who was stationed at Wad Medani. In this connexion, a survey of anopheles mosquitoes was carried out in the Gezira Irrigation Scheme. The two main breeding places for Anopheles gambiae were found to be pools in the minor irrigation canals watering cotton (18.7 larvae per square metre) and flooded dura (sorghum vulgare) plots (33.2 larvae per square metre); the seasonal distribution of larvae in the canals showed two annual peak periods, March-April and October-November. ${ }^{17}$ The results obtained from the larval survey afforded some useful information for modifying control methods in the localized breeding places around population centres.

There was also the yellow fever serological survey of southern and western Sudan which was started by Dr. Hewer of the Wellcome Tropical Research Laboratories in 1934 and carried on by Dr. R. Kirk. Sera were collected and sent in sealed ampoules to Dr. G. M. Findlay of the Wellcome Bureau of Scientific Research in London for mouse protection tests. The results of this extensive survey showed immunity to the disease in many parts of southern and western Sudan, and indicated that there had been a widespread sub-clinical infection with the yellow fever virus throughout the Nuba Mountains area in the previous twenty years. ${ }^{18}$ When yellow fever struck the Nuba Mountains in 1940 the results of this survey were valuable in drawing comparisons. Aedes aegypti, although present in the area with a high larval index between 28 and 98 per cent, ${ }^{19}$ was not definitely incriminated for the epidemic spread of the disease. Aedes vittatus was suggested as the principal vector and Aedes luteocephalus a vector of some importance. ${ }^{20}$ Collaboration with the Yellow Fever Research Institute at Entebbe (Uganda) was invaluable in confirming the diagnosis and initiating control measures to stem the tide of the epidemic. Despite wartime difficulties Dr. A. F. Mahaffy of the International Division of the Rockefeller Foundation and Director of the institute came to the Nuba Mountains epidemic area and isolated 


\section{A. Bayoumi}

(in mice) from the blood of patients two strains of virus which he later identified in Entebbe as yellow fever. ${ }^{21}$ It was due to his initiative that the Rockefeller Foundation and the Wellcome Institute of Scientific Research rendered great assistance by supplying a consignment of the famous 17D vaccine to inoculate medical and other personnel in the area which enabled them to carry on without danger of infection. This was the first employment of the now world-wide vaccine in an epidemic of the disease in Africa.

Besides dealing with emergency research problems, it did not take long for the Stack Laboratories to proceed from this limited orbit of research activity to more ambitious epidemiological, operational and basic research projects. Kala-azar, cerebrospinal meningitis, relapsing fever, smallpox, enteric fever, rabies, diphtheria, and onchoserciasis were but a few examples of the diseases which were investigated from practical as well as purely research angles. From their inception the laboratories were associated with the teaching programmes of the Kitchener School of Medicine and continued to participate actively throughout their long history. Their close collaboration over many years with the public health authorities in Khartoum and the provinces in the investigations of diseases must be commended and in this respect a railway laboratory saloon was of great help in carrying out research and routine work far from Khartoum. Besides these outstanding contributions, medico-legal tests carried out for the legal authorities formed an important part of the work of the Stack Laboratories.

Concurrently with the reorganization of medical research services in 1935, the Stack Laboratories started a series of experiments with a view to establishing a vaccine lymph institute in Khartoum; the reason being that the imported vaccine lymph was losing potency in the country's hot climate, thus giving unsatisfactory results. Successful experiments were conducted using strains of vaccine obtained from Dr. McClean at the Lister Institute, Elstree; and with the collaboration of the Senior Veterinary Research Officer the vaccine institute of the laboratories started to produce glycenrated calf lymph on a mass scale in $1937 .{ }^{22}$ In 1940 sheep were substituted for calves in the preparation of lymph vaccine on account of cleanliness and greater yield of vaccine lymph. In addition to vaccine lymph other standard vaccines prepared at the laboratories were rabies, T.A.B. and cholera.

Whatever the problems and difficulties, the growth of medical research in the Sudan reached its zenith during the 1940s at the end of which decade Robert Kirk became the last British head of medical research in the Sudan, a position which he held till 1952 when he became the first Professor of Pathology in the Faculty of Medicine (previously Kitchener School of Medicine) of the University College of Khartoum. In the twenty-one years of his career in the Sudan, Kirk conducted research into most of the common diseases and his outstanding efforts were responsible for an advance in medical research from the limited smaller projects to well-co-ordinated research plans. He achieved notable success by his investigations, among many, into kala-azar and in this respect he led a team of workers the core of which was Dr. Satti, one of the pioneering Sudanese researchers, and Mr. Lewis, the medical entomologist. The team carried out studies on the chemotherapy and transmission of leishmaniasis. It established sodium antimony gluconate (pentostam) 
as a satisfactory therapeutic agent for kala-azar, worked on the distribution and bionomics of sandflies and suggested, on epidemiological grounds, Phlebotomus papatasi as the probable vector of oriental sore and Phlebotomus orientalis as the most likely one of kala-azar. ${ }^{23}$

On account of his contributions to tropical medicine, Kirk was awarded the Chalmers Medal of Tropical Medicine and Hygiene in 1943 and ten years later the same honour was conferred on Mr. D. J. Lewis for his outstanding performance in the field of medical entomology in the Sudan especially with regard to malaria, trypanosomiasis, leishmaniasis and ochocerciasis. A comprehensive list of research publications about the Sudan is included in the Bibliography of the Sudan 1938-1958. ${ }^{24}$

\section{HISTORY OF THE ORGANIZATION OF MEDICAL RESEARCH 1949-1974}

With the creation of the Sudanese Ministry of Health in 1949 and the subsequent Sudanization of senior posts, Kirk was succeeded by Dr. M. A. Haseeb as Assistant Director for Research in 1952. As the first Sudanese doctor to join the Stack Laboratories, Haseeb started his postgraduate training in the laboratories in 1936. In 1938 he attended a course in the laboratories of the London County Council and in 1946 he obtained the Diploma in Bacteriology of the London School of Tropical Medicine and Hygiene.

Simultaneously with the beginning of his leadership, an important development took place in regard to the training of Sudanese laboratory workers. In 1952 a unified policy was adopted for the training of laboratory assistants throughout the country; and southern laboratory assistants who used to be trained at Juba Hospital started to receive the same instruction as their northern colleagues at the Stack Laboratories in Khartoum. The school for laboratory assistants was also developed into a regional training centre of the World Health Organization during Haseeb's era.

In 1953-1954 the training of laboratory technicians was started and candidates were recruited from among secondary school graduates for a three-year course in advanced bacteriology, haematology, pathology and biochemistry. The annual report for that year hailed this pioneering venture as being a fulfilment of "a long felt desire to employ Sudanese technicians with a good basic education in the Natural Sciences". 25

Another important development during Haseeb's era coincided with the admission of the country into the international arena after becoming an independent state in 1956. Besides the World Health Organization's concerted effort to help the country deal with its major public health problems, the United States Naval Medical Research Unit Number Three started a five-year investigation (1960-1964) to elucidate the epidemiology of visceral leishmaniasis-kala azar-in the Sudan. ${ }^{26}$

In 1963 Professor Haseeb, besides being the first graduate of the Kitchener School of Medicine to fill a Chair (of Bacteriology) in the Faculty of Medicine of the University of Khartoum, also became its first Sudanese Dean. He served as Dean from 1963 to 1969 and as full-time professor of microbiology and parasitology until his death in September 1973. Shortly before his death Professor Haseeb was awarded the Dr. A. T. Shousha Foundation Prize established in memory of the first Director of the Eastern Mediterranean Region of the World Health Organization 


\section{A. Bayoumi}

and given for outstanding service to medicine in the area. Awarding the prize, the President of the Twenty-Sixth World Health Assembly, Dr. Julie S. Saroso, said that for a period of thirty-nine years Professor Haseeb had served the cause of medical education and research in the Sudan with distinction and single-minded devotion.

The directorship of the Stack Laboratories became the responsibility of Dr. M. H. Satti, another of the country's pioneer research workers, whose major contributions in the field of leishmaniasis led to his discovery of a new experimental host for the disease-the bush-baby Galago senegalensis-which he considered better than the hamster. ${ }^{27}$ Satti's leadership marked the beginning of a concerted programme for the postgraduate training of young Sudanese researchers in the United Kingdom to cater for future expansion of medical research activities in the Sudan.

Three years after he assumed office, Dr. Satti was the first director of medical research to advance the plea that research in general should be looked upon by the state as a necessity and not a luxury in the interest of progress and development, and to put concrete proposals for co-operation in medical research through the establishment of a Medical Research Council and a School of Tropical Medicine: “. . I I am struck and in reality perturbed by the great numbers of medical problems in this country that shout and press for solution. This cannot be carried out without intensive research, which necessitates the exploitation of all our available scientific manpower regardless of the differences of the units, institutions or ministries to which they belong. Because of the limited number of these scientific personnel, active co-ordination and co-operation of such work should be encouraged between various workers and particularly between those in the Ministry of Health and the University. ..."28

Satti's principal recommendation concerned the establishment of a medical research council to organize medical research work in the country and the spending of funds in the best public interests. This proposal was augmented by a call to start "some form of a school of tropical medicine with a big team of teachers and research workers in the various fields of tropical medicine with particular emphasis on local Sudanese problems." ${ }^{29}$ This latter issue, Satti asserted, should start under the auspices of the university with moral and material support from the Ministry of Health; and in support of this he maintained: "This is considered very essential and urgent in view of the fact that we are now absorbing in the service very many doctors who had been trained in Europe and other non-tropical countries who have never been exposed to tropical medicine at all. This is not fair on either side, both on the doctors and patients. This state of affairs might lead to some loss of life and no doubt this situation needs to be quickly remedied." 30

Satti further elaborated that "co-operation in research should be established with other institutes and ministries besides the University"-like the Division of Agricultural Research and Veterinary Research-as there were many problems of common interest e.g. nutrition, pest control and the use of insecticides and molluscicides. In support of his specific proposal for the establishment of a National Scientific Organization, he asserted that: "The organization of research workers on the basis of specialization and ability into teams will be very beneficial to the country at large and should be embarked upon forthwith. There is no place in the world of 


\section{Medical research in the Sudan since 1903}

today for a nation that is not preparing itself to take an active part in the scientific development and welfare of mankind."31

These proposals did not meet with adequate response at the time; but when, four years later, plans were being made for the future development of scientific research in the Sudan, Satti's proposals were reconsidered.

Before dealing with recent changes in the structure of medical research, some other important developments in the history of scientific research in the Sudan which took place during the last two decades deserve to be mentioned. In 1953 the Sudan Medical Journal was launched as an official organ of the Sudan Medical Association and a vehicle of scientific communication to help individual researchers in the medical and allied fields in channelling their research findings to the Sudanese medical profession and in reflecting their activities to the outside world. The journal, however, faced some financial difficulties which interrupted its publication a few years later; but the present new series which was started in 1962 with government support is still coming out regularly.

While it is no doubt true that the Sudan Medical Journal published papers dealing with aspects of some of the major public health problems of the country, it generally contained articles tackling clinical problems of limited scope and interest. This unequal distribution was not due to editorial policy, but rather to shortcomings of Sudanese public health workers to throw enough light on the problems of community medicine. "Community physicians" are required to apply new concepts in the academic pursuit of knowledge in the preventive field. In the Sudan there are hopeful signs as more and more keen young doctors are joining the field to meet the challenge. The whole image of community medicine in the Sudan in respect to research, teaching and operational activity shall for a long time continue to be the make-or-break issue in the development of medical care; and it is hoped that frustration and job dissatisfaction will not quench these efforts.

In 1951 the Gordon Memorial College became the University College of Khartoum and was licensed for degree courses from the University of London. By 1956 the status of the University College of Khartoum was raised to that of the University of Khartoum, and started in 1958 to grant its own degrees. The Kitchener School of Medicine, incorporated in the University College of Khartoum in 1951 and amalgamated as the Faculty of Medicine of the University of Khartoum in 1956 (hitherto granting its own diploma, D.K.S.M.), started to offer the degree of M.B., B.S. (Khartoum) in 1959. This status of university independence in academic matters, which was the fruit of more than half a century of slow but sure development, paved the way for the beginning of postgraduate studies in medicine and other branches of knowledge. Higher degrees in medicine which had been hitherto mainly channelled to the United Kingdom, started to be accepted in the Faculty of Medicine, University of Khartoum. Appendix 1 shows medical theses on the Sudan accepted by universities in the United Kingdom and Ireland during the period 1920-1965, as published by the Standing Conference on Library Material on Africa. ${ }^{32}$ Medical theses accepted by the University of Khartoum since 1963 are given in Appendix $2 .{ }^{33}$

In 1964 Sir Graham Wilson, ex-director of the Public Health Laboratories of England and Wales, was invited to the Sudan to advise on the reorganization of 


\section{A. Bayoumi}

laboratory services. He made several proposals ${ }^{34}$ which, besides being discussed with Professor Haseeb and Dr. Satti, were also a subject of further consultation with Professor B. G. Maegraith, Dean of the Liverpool School of Tropical Medicine. While advising that reduplication of services should be avoided, Sir Graham Wilson pointed out that preventive medicine and public health laboratory services were lagging behind clinical medicine. Little, he maintained, was being done to integrate epidemiology with laboratory work, or to conduct surveys to secure substantial data about the incidence of various communicable diseases essential in the practice of preventive medicine. In this connexion he added that there was a pressing need for a high-quality public health and epidemiological service to carry out routine surveys and investigations of communicable diseases; all routine work, he asserted, should be approached in the research spirit. Wilson's recommendations included the following points: (1) the formation of a national laboratory service under a special board appointed by the government; (2) the accommodation of the departments of microbiology, pathology, parasitology, entomology and epidemiology in the new laboratory buildings which should act as a central public health laboratory and a nucleus for work on communicable diseases; (3) the building up of mobile epidemiological units to be attached to the central laboratories with the aim of extending services to the periphery; (4) the training of more technicians to fill in the gaps between the humble laboratory assistant in the provinces and the higher echelon of laboratory staff in Khartoum.

Wilson's recommendations, however, were partially adopted when in 1970 the National Public Health Laboratories were inaugurated. Besides integrating the Stack Laboratories, the Wellcome Chemical Laboratories and the Entomological Laboratories, they also housed the Departments of Pathology and Microbiology of the Faculty of Medicine. In 1972 the Minister of Higher Education and Research appointed a board to run the new organization. Thus, for the first time, research workers belonging to both the Ministry of Health and the University rendered a joint service in the same building.

In May 1970 the establishment of a National Council for Research was enacted by a Presidential Decree and was described as the most suitable form of organization to fulfil the following objectives: (1) to effect co-ordination in research and scientific activities; (2) to formulate and follow up the nation's science policy especially in the field of research and development; (3) to render advice to the government particularly in the field of training of scientific manpower and in the field of transfer, adaptation and use of technology in the development of the country; (4) to create a healthy productive atmosphere for scientists and researchers with the purpose of fully utilizing their knowledge and energy in the solution of problems facing the country's natural and human resources.

In October 1971 a further step was taken in the way of organizing and co-ordinating research activities in the Sudan when a new Ministry of Higher Education and Research was created. This ministry was dissolved in 1973, but the National Council for Research continued to function as an independent body. Although the need had long been felt in the Sudan for a national research organization, these seemingly ideal developments were met with reserve by scientific public opinion in the country. 


\section{Medical research in the Sudan since 1903}

Disagreement among scientists developed over the questions of determining the future of existing research bodies and the organizational hierarchy of the new one. Some research circles threw an unfavourable light on the creation of a national research body and the appointment of a superstructure for it by a decision from the top. In spite of this opposition, the National Council for Research started to function. Its activities were channelled into five sub-councils, namely: the Agricultural, the Animal Resources, the Economic and Social, the Industrial and the Medical Research Councils.

From its very early meetings the Medical Research Council was guided by the scientific spirit that the problems of medical research in this country represent a challenge to the profession and that a change in the strategy of medical care in the Sudan is an urgently needed tonic. In setting out its objectives, the Medical Research Council deliberately tried to find a new formula for integrating what had been hitherto separated in practice: research from teaching; teaching from action and action from research. To serve this broad conception, it has embarked on the task of organizing its research strategies around the major public health problems. Five basic priority groups could be formulated after consultation through the medium of a questionnaire cast to the medical profession: ${ }^{85}$ tropical diseases (e.g. malaria, schistosomiasis, cerebrospinal meningitis, leishmaniasis), childhood diseases, problems of malnutrition, establishing physiological norms in Sudanese, and the control of tuberculosis. These priorities were claimed to be only preliminary steps in a long and tedious path to fill the medical research vacuum in the Sudan.

In 1972 the Medical Research Council established an Institute for Tropical Medicine to cater for the research priorities in this field. A base hospital for Tropical Medicine was established in Omdurman in collaboration with the Ministry of Health. These two institutions are to be run by tripartite Boards of Management representing the Ministry of Health, the Faculty of Medicine and the Medical Research Council to ensure the pooling of efforts. The Council adopted a working system based on shortterm research projects with specific objectives preferably to be led by multidisciplinary teams. While these projects may use the facilities of the institute and the hospital, local research stations will be established wherever feasible to facilitate their smooth running. This suggested organization of medical research activities is represented diagrammatically in Figure $1 .^{36}$ Several projects were already under way in 1974: the Bilharzia Project (Gezira) in collaboration with the London School of Hygiene and Tropical Medicine which supports the project through the Wellcome Trust, the Cerebrospinal Meningitis Research Project, the Schistosomiasis Research Project (western Sudan), the Leishmaniasis Research Project, the Goitre Research Project (Darfur) and the Research Project on the Sudan Atlas of Disease Distribution.

\section{CONCLUSION}

The inauguration of a medical research organization in the Sudan early in the century was not only a significant development in the medical history of this country, but also an important one on a continent-wide basis. Generally speaking, it may be maintained that the history of organized research in the Sudan reflects the development of health services. The growth of the Wellcome Research Laboratories from a 


\title{
ORGANISATION OF MEDICAL RESEARCH ACTIVITIES
}

\author{
Ministry of \\ Higher Education and Research \\ $\downarrow$ \\ National Council for Research \\ (Multidisciplinary) \\ Medical Research Council \\ (Multidisciplinary)<smiles>[3H]</smiles> \\ Institute for Tropical Medicine \\ (Tripartite B. of M.) \\ Base Hospital for Tropical Medicine \\ (Tripartite B. of M.)

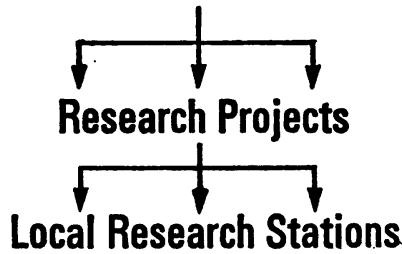

Figure 1

semi-official body in 1903 to a full-fledged government agency in 1935 was a fruitful result of a growing co-operation with the Sudan Medical Service and coincided with its reorganization into a multi-disciplinary department. It is no doubt true that the role of the research factor was a very important one in the development of Sudan health services and in the shaping of medical policy.

Medical research is still a frontline task for solving the major public health problems of the Sudan: communicable diseases, malnutrition and childhood mortality. It is also a great tower of strength for driving home the vital issue that the battle against disease is not only a public health problem but also a social and economic one with far-reaching administrative and political repercussions. It is only when medical research is seen from this perspective that medical care can contribute effectively to national development. There is no better statement to serve as a conclusion to this paper than the words of Gordon Smith who emphasized that: "The now developing countries have to tackle even more complex disease problems against a background 
elsewhere of rapid technological and scientific progress, much of which is not readily adaptable to their circumstances of galloping population increase, widespread malnutrition and the growing pains of an industrial revolution."37 Without underestimating the power of technological trends, there are some potent forces on our side, if only we utilize them: a comprehensive and holistic attitude to meet the challenge; the organization of research around genuine problems rather than around variables disciplines or factors; and the deliberate integration of research, teaching and action to increase their potential for future development.

\section{REFERENCES}

1. A. Balfour, First report of the Wellcome Research Laboratories, Khartoum, Sudan Government, 1904, p. 7.

2. Ibid., pp. 11-13.

3. Ibid., p. 13.

4. Ibid.

5. A. Balfour, Second report of the Wellcome Research Laboratories, Khartoum, Sudan Government, 1906.

6. A. Balfour, Third report of the Wellcome Research Laboratories, Khartoum, Sudan Government, 1908.

7. A. Balfour, Fourth report of the Wellcome Research Laboratories, Khartoum, Sudan Government, 1911, vol. A.

8. Ibid., vol. B.

9. A. Balfour and R. G. Archibald, Review of some of the recent advances in tropical medicine (Supplement to the third report of the Wellcome Research Laboratories), Khartoum, Sudan Government, 1908.

10. A. Balfour and R. G. Archibald, Second review of the recent advances in tropical medicine (Supplement to the fourth report of the Wellcome Research Laboratories), Khartoum, Sudan Government, 1911.

11. J. B. Christopherson and J. R. Newlove, 'Laboratory and other notes on seventy cases of bilharzia treated in Khartoum Civil Hospital by intravenous injections of antimony tartrate', J. trop. Med. Hyg., 1919, 26: 129-144.

12. H. S. Squires, The Sudan Medical Service-an experiment in social medicine, London, William Heinemann, 1958, p. 96.

13. [United Kingdom], 'Report of the Departmental Committee appointed by the Secretary of State for the Colonies to enquire into the Office of Colonial Medical Services ...', Parliamentary Papers, 1920, 13 : 11.

14. A. Beck, A history of the British medical administration of East Africa 1900-1950, Cambridge, Mass., Harvard University Press, 1970, p. 179.

15. R. Hill, A bibliographical dictionary of the Anglo-Egyptian Sudan, London, Oxford University Press, 1939.

16. E. S. Horgan, Annual report of the Sudan Medical Service, Khartoum, Ministry of Health, 1935, p. 69.

17. Bedford, Annual report of the Sudan Medical Service (entomology report), Khartoum, Ministry of Health, 1936, p. 83.

18. Annual report of the Sudan Medical Service, Khartoum, Ministry of Health, 1936, p. 77.

19. Ibid., 1940, p. 58.

20. D. J. Lewis, 'Mosquitoes in relation to yellow fever in the Nuba Mountains, AngloEgyptian Sudan', Ann. trop. Med. Parasit., 1943, 37: 65-67.

21. A. F. Mahaffy, T. P. Hughes, K. C. Smithburn and R. Kirk, 'The isolation of yellow fever virus in the Anglo-Egyptian Sudan', ibid., 1941, 35: 141-148.

22. Annual report of the Sudan Medical Service, Khartoum, Ministry of Health, 1937, p. 72. 


\section{A. Bayoumi}

23. R. Kirk and D. J. Lewis, 'Studies in leishmaniasis in the Anglo-Egyptian Sudan. XI. Phlebotomus in relation to leishmaniasis in the Sudan', Trans. R. Soc. trop. Med. Hyg., 1955, 49: 229-240.

24. A. R. el Nasri, A bibliography of the Sudan 1938-1958, London, Oxford University Press, 1962.

25. Annual report of the Sudan Medical Service, Khartoum, Ministry of Health, 1953-1954, p. 36.

26. H. Hoogstraal and D. Heyneman, 'Leishmaniasis in the Sudan Republic', Am. J. trop. Med. Hyg., 1969, 18 (supplement): 1091-1210.

27. M. H. Satti, Annual report of the Sudan Medical Service, Khartoum, Ministry of Health, 1962-1963, p. 47.

28. M. H. Satti, 'Memorandum on co-operation in medical research . . ., ibid., 1965-1966, p. 65.

29. Ibid., p. 66.

30. Ibid., p. 66.

31. Ibid., p. 66.

32. Standing Conference on Library Material on Africa, Theses on Africa accepted by universities in the United Kingdom and Ireland, Cambridge, Heffer, 1964.

33. University of Khartoum, personal communication, 1974.

34. Sir Graham Wilson, 'Report on the reorganisation of laboratory services in the Sudan', Khartoum, Ministry of Health, 1964 [unpublished].

35. A. Bayoumi, 'The Medical Research Council in the Democratic Republic of the Sudan', Khartoum, National Council for Research, 1972 [duplicated], pp. 11-12.

36. Ibid., p. 15.

37. C. E. G. Smith, 'Changing patterns of diseases in the tropics', Br. med. Bull., 1972, 28: 3-9.

\section{APPENDIX 1}

\section{MEDICAL THESES ON SUDAN ACCEPTED BY UNIVERSITIES IN THE UK AND IRELAND 1920-1965}

P. H. Abbott, Mycetoma: A clinical and epidemiological study. M.D., Cambridge, 1954.

J. D. Bates, Tumours in Sudanese. M.D., Liverpool, 1959-1960.

J. Bryant, A description of investigations carried out in the Equatoria Province of the Anglo-Egyptian Sudan on hitherto undescribed disease of the eyes now known as "Sudan Blindness"; together with an account of the manifestations of Onchocerca volculus (Leuckart, 1893), notes on the parasite and its relations to "Sudan Blindness". M.D., Edinburgh, 1936-1937.

R. M. Buchanan, On schistosomiasis: a comparative study of the condition found in Berber Province, Anglo-Egyptian Sudan, with reference to recent literature. M.D., Glasgow, 1935.

A. Cruickshank, Onchocerca volvulus (Leuckart), its occurrence in the Southern Anglo-Egyptian Sudan and its significance in the etiology of endemic blindness. M.D., Aberdeen, 1934.

C. C. Finlator, The prophylaxis of malaria in the Sudan. M.D., Glasgow, 1909.

W. H. Greavy, A survey of schistosomiasis in the Gezira Irrigated Area of the Anglo-Egyptian Sudan, with special reference to the intestinal type. M.D., Oxford, 1950-1951.

R. Kirk, The epidemiology of relapsing fever in the Anglo-Egyptian Sudan. M.D., Glasgow, 1940.

A. Leach, A thesis on the Pharaonic and Sunna forms of circumcision as performed on females in the Anglo-Egyptian Sudan. M.D., Belfast, 1947.

T. P. Parr, Bilharziasis in the Sudan. M.D., Edinburgh, 1935-1936.

J. T. Robinson, African schistosomiasis, with special reference to its occurrence in the Sudan. M.D., Dublin, 1933-1934.

E. S. Mahgoub, Mycetoma infections in the Sudan. Ph.D., London, 1965.

R. B. F. Somers, A review of epidemic cerebrospinal fever as it occurs in the Sudan with special reference to an outbreak in the Cabe District and its control by sulphanibyl amids pyridine, M \& B 693. M.D., Birmingham, 1941. 


\section{APPENDIX 2}

\section{MEDICAL THESES ACCEPTED BY THE UNIVERSITY OF KHARTOUM 1963-1974}

Muncus, The vascular and tubular structure of the mammalian kidney in relation to water consideration. Ph.D., 1963.

M. M. Hassan, Congenital disease in Sudanese children. M.D., 1966.

O. Modawi, A study of infertility in the Southern Provinces. M.D., 1966.

M. Yousif, A study of the vital statistics, social and environmental conditions of Hag Yousif rural community. M.D., 1968.

M. Khogali, Lung diseases among cotton ginnery workers. M.D., 1969.

A. Kambal, Endemic goitre in Darfur. M.S., 1969.

M. A. Hassan, Gastric secretion studies in health and disease. M.S., 1970.

B. Hamad, Some sociological and mental health studies in Khartoum University students. M.D., 1973.

S. A. A. Taha, Protein-calorie malnutrition in children of the Gezira main irrigated area in the Sudan. M.D., 1973.

M. M. Beiram, Onchocerciasis in the Sudan. M.D., 1974.

A. Bayoumi, The history and development of Sudan health services. M.D., 1974. 